\title{
Assessing the effect of pregnancy stage on milk composition of dairy cows using mid-infrared spectra
}

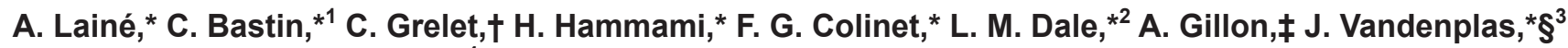 \\ F. Dehareng, $\dagger$ and N. Gengler* \\ *Agriculture, Bio-engineering and Chemistry Department, Gembloux Agro-Bio Tech, University of Liège, B-5030 Gembloux, Belgium \\ †Walloon Agricultural Research Center (CRA-W), Valorization of Agricultural Products Department, B-5030 Gembloux, Belgium \\ $\ddagger$ Walloon Breeding Association (awé), B-5530 Ciney, Belgium \\ $\S N a t i o n a l$ Fund for Scientific Research, B-1000 Brussels, Belgium
}

\section{ABSTRACT}

Changes in milk production traits (i.e., milk yield, fat, and protein contents) with the pregnancy stage are well documented. To our knowledge, the effect of pregnancy on the detailed milk composition has not been studied so far. The mid-infrared (MIR) spectrum reflects the detailed composition of a milk sample and is obtained by a nonexhaustive and widely used method for milk analysis. Therefore, this study aimed to investigate the effect of pregnancy on milk MIR spectrum in addition to milk production traits (milk yield, fat, and protein contents). A model including regression on the number of days pregnant was applied on milk production traits (milk yield, fat, and protein contents) and on 212 spectral points from the MIR spectra of 9,757 primiparous Holstein cows from Walloon herds. Effects of pregnancy stage were expressed on a relative scale (effect divided by the squared root of the phenotypic variance); this allowed comparisons between effects on milk traits and on 212 spectral points. Effect of pregnancy stage on production traits were in line with previous studies indicating that the model accounted well for the pregnancy effect. Trends of the relative effect of the pregnancy stage on the 212 spectral points were consistent with known and observed effect on milk traits. The highest effect of the pregnancy was observed in the MIR spectral region from 968 to $1,577 \mathrm{~cm}^{-1}$. For some specific wavenumbers, the effect was higher than for fat and protein contents in the beginning of the

\footnotetext{
Received July 14, 2016.

Accepted November 23, 2016.

${ }^{1}$ Current address: Walloon Breeding Association (awé), B-5530 Ciney, Belgium.

${ }^{2}$ Current address: Landesverband Baden-Württemberg für Leistungs- und Qualitätsprüfungen in der Tierzucht e.V., 70190 Stuttgart, Germany.

${ }^{3}$ Current address: Animal Breeding and Genomics Centre, Wageningen UR, Livestock Research, 6700 AH Wageningen, the Netherlands.

${ }^{4}$ Corresponding author: nicolas.gengler@ulg.ac.be
}

pregnancy (from 30 to 90 or $120 \mathrm{~d}$ pregnant). In conclusion, the effect of early pregnancy can be observed in the detailed milk composition through the analysis of the MIR spectrum of bovine milk. Further analyses are warranted to explore deeply the use of MIR spectra of bovine milk for breeding and management of dairy cow pregnancy.

Key words: dairy cow, pregnancy, milk mid-infrared spectrum

\section{INTRODUCTION}

Pregnancy is an essential requirement for a dairy cow to start and to maintain her productive life. But pregnancy puts also an internal stress on the producing animal, as it needs to partition energy between different physiological functions. Therefore, the status of being pregnant is known to influence milk yield and major milk components (e.g., lactose, fat, and protein). Different studies have quantified the effect of pregnancy on milk, fat, and protein yields and contents (Olori et al., 1997; Loker et al., 2009; Penasa et al., 2016). Olori et al. (1997) reported a depression in milk, fat, and protein yields from the first month of pregnancy, with a significant decrease from the fifth month of pregnancy assuming a constant effect of the lactation stage. In the same way, Olori et al. (1997) reported that fat, protein, lactose, and solids contents at the eighth month of gestation were higher by $2.6,0.2,0.1$, and 2.9 $\mathrm{g} / \mathrm{kg}$, respectively, for nonpregnant cows. Loker et al. (2009) reported a decrease in yields from the start of the pregnancy for Canadian Ayrshire, Jersey, Brown Swiss, and Guernsey dairy cows. More specifically, the significant decrease of milk and fat yields began in the fourth month of pregnancy, and the significant decrease of protein yield began in the second month of pregnancy. For Ayrshire dairy cows, the loss in milk, fat, and protein yields estimated by Loker et al. (2009) was of $3.7,3.2$, and $6.6 \%$, respectively, at the fifth month of pregnancy. Recently, Penasa et al. (2016) investigated 
the effect of pregnancy stage on milk coagulation properties and showed a continuous improvement of these properties from the beginning to the end of pregnancy. They argued that this is probably due to the higher percentage of solids components in milk observed at that stage of pregnancy. Finally, Bohmanova et al. (2009) have shown that introducing the pregnancy status in genetic evaluation will considerably improve the goodness of fit of the models and, therefore, give more accurate breeding values. All these results confirmed that milk composition is influenced by the pregnancy status of dairy cows (pregnant versus nonpregnant) and varies according to the stage of pregnancy. However, to our knowledge, on a larger scale, only the pregnancy effect on major milk components has been investigated. Changes in minor milk components due to pregnancy can also be expected; in particular, progesterone profiles in milk have been reported to be different between a pregnant and a nonpregnant cow due to pregnancy and related endocrine changes (Friggens and Chagunda, 2005). Pregnancy-associated glycoproteins are a group of proteins specific to pregnancy that are synthesized and secreted by the placental tissue and are present in blood and in milk (Gajewski et al., 2008). On a larger scale, pregnancy effects on the whole detailed milk composition, meaning on major and on minor milk components, must still be investigated.

Milk laboratories provide a wide range of analyses, and results are routinely used by organizations advising dairy farmers in their management choices. The same results are often also used as phenotypes for the evaluation of the genetic potential of the animals. Fourier transform mid-infrared (FT-MIR) spectroscopy is the worldwide method of choice for the analysis of milk; FT-MIR allows high-throughput, low-cost, and large-scale analysis of milk that can provide qualitative and quantitative information on milk composition. Therefore, within official milk-recording schemes, most countries use FT-MIR to predict the major milk components (i.e., fat, protein, lactose, and urea contents; De Marchi et al., 2014). In recent years, intensive research has used FT-MIR also in the prediction of other, more minor, milk components, such as fatty acid (FA) profile (Soyeurt et al., 2006; Rutten et al., 2009, Soyeurt et al., 2011), protein composition (Bonfatti et al., 2011), and mineral content (Soyeurt et al., 2009) in relation with milk coagulation properties (Toffanin et al., 2015), and also other milk composition-related phenotypes, such as body energy status (McParland et al., 2011; McParland and Berry, 2016), ketone bodies (van Knegsel et al., 2010; Grelet et al., 2016) and hyperketonomia status (van der Drift et al., 2012), or methane emissions (Vanlierde et al., 2015). Along with this nonexhaustive list of milk components or pheno- types that can be predicted by FT-MIR, this method is also recognized as a convenient approach to convert spectral data (Gengler et al., 2016) into information on milk quality (e.g., FA composition and milk coagulation properties), cow health, or other traits of interest in management and breeding (De Marchi et al., 2014). Therefore, it is consensus that the main components of milk as well as detailed milk composition can be assessed through the mid-infrared (MIR) spectra obtained from the FT-MIR analysis of milk.

Usually, MIR spectra are used to predict a specific milk component (i.e., FA, minerals, or ketone bodies) by using the spectral data as predictors and the reference value of the components to be predicted as the response variable (Soyeurt et al., 2006; Grelet et al., 2015). Other innovative ways to use spectral data exist. As shown by several authors (e.g., Soyeurt et al., 2010; Dagnachew et al., 2013; Wang et al., 2016), MIR spectral data points (wavenumbers) can be considered traits reflecting detailed milk composition and can then be analyzed by genetic models. Considerable phenotypic and genetic variation in these traits has been shown; therefore, the next step is to study the origin of the observed phenotypic variation in these traits.

The aim of our study was to investigate the effect of pregnancy status on the detailed milk composition of primiparous Holstein cows assessed through the MIR spectra obtained from the routine FT-MIR analysis. The strategy we followed was therefore to consider MIR spectra as response variables to a given internal stress, the status of being pregnant. The effect of pregnancy on MIR spectra was compared with its known effect on milk yield, fat, and protein contents through all stages of pregnancy. This research could provide elements that will permit to adapt current genetics models by introducing the effect of the pregnancy stage, which may lead to new approaches for determining the pregnancy status of dairy cows directly from routine milk analysis. However, this may only be possible if the effect of the pregnancy status is known on predictors expected to be used to determine the pregnancy status of dairy cows; thus, the MIR spectra was the aim of our study.

\section{MATERIALS AND METHODS}

\section{Data}

Data used was collected between January 2012 and November 2014 by the milk-recording organization of the Walloon Region of Belgium, the Walloon Breeding Association (Ciney, Belgium). A total of 56,902 test-day (TD) records from the first lactation of 9,757 Holsteins and Red-Holsteins cows within 156 Walloon herds were selected. Those herds were enrolled in specific programs 
generating high-quality fertility and insemination records. A total of 22,151 dates of inseminations were available with an average of $2.3( \pm 1.7)$ inseminations per animals. Observation ranged from 5 to 365 DIM. For all these TD, milk yield, fat, and protein contents were available and only data within the range of ICAR norms (ICAR, 2012) for these milk traits were kept. Pedigree data included 39,108 animals extracted from the database used for the official Walloon genetic evaluation and limited to animals born after 1985 .

The pregnancy status, defined as pregnant or nonpregnant, associated with each TD record was determined as follows. The average gestation length of primiparous Holstein cows was set to 282 d, as it is used by the breeding organization in Wallonia, and the pregnancy confirmation was the second calving of these cows. The conception date for a cow with a pregnancy confirmation was determined as the last insemination date performed $282 \pm 14 \mathrm{~d}$ before the second calving. For a cow with a pregnancy confirmation, TD records occurring between the first calving and the conception date were set to the nonpregnant status, whereas TD records occurring after the conception date were set to the pregnant status. For a cow with no pregnancy confirmation, TD records occurring before the first insemination recorded were set to the nonpregnant status, whereas TD records occurring after that first insemination were discarded. All TD records with of cows with no insemination and no pregnancy confirmation were set to the nonpregnant status. The number of days pregnant $(\mathbf{d P})$ at a specific TD was calculated as the number of days between the TD and the insemination date identified as the conception date. The $\mathrm{dP}$ was used to define the pregnancy stage.

\section{MIR Spectra of Milk}

All milk samples collected during the conventional milk recording protocol were analyzed by 3 spectrometers MIR MilkoScan FT6000 (Foss, Hillerød, Denmark) at the milk laboratory Comité du Lait (Battice, Belgium). Resulting MIR spectra were expressed in absorbance, with 1,060 spectral points covering the absorption of light from 900 to $5,000 \mathrm{~cm}^{-1}$ wavenumbers. First derivative was calculated on the raw spectra as the difference between the spectral point $\mathrm{X}$ and the spectral point $\mathrm{X}+5$ to set all spectra at a common baseline (McParland et al., 2011). All spectra were standardized using the piecewise direct standardization within a European network to reduce the instrument-to-instrument variability, as described in Grelet et al. (2015). This standardization of machines allows reducing the variability in spectral analysis among spectrometers and over time (Grelet et al., 2015). Finally, spectral outliers were removed based on a value of over 5 for the standardized Mahalanobis distance of the spectral data set.

Due to their low signal-to-noise ratio, some MIR spectral regions cannot be used for calibration of milk components and, therefore, for further study on MIR spectra (Rutten et al., 2009; Bonfatti et al., 2011; Vanlierde et al., 2015; Grelet et al., 2016). Based on previous studies and on the known areas of water absorption, only 212 spectral points out of the 1,060 were kept for our study. Wavenumbers covered by these 212 spectral points are from 968 to $1,577 \mathrm{~cm}^{-1}$; from 1,732 to $1,763 \mathrm{~cm}^{-1}$; from 1,782 to $1,809 \mathrm{~cm}^{-1}$; and from 2,831 to $2,966 \mathrm{~cm}^{-1}$. These informative areas are similar to those used in previous studies that aimed to calibrate MIR predictive equations (e.g., for milk composition; Vanlierde et al., 2015; Grelet et al., 2016).

\section{Model}

A univariate model was applied on milk production traits (milk yield, fat, and protein contents) and on the 212 spectral points. For the trait $i$ and a record $t$ of cow $q$ in herd $p$, the model was defined as follows:

$$
\begin{aligned}
& y_{i j k p q t}=H_{T D}+\operatorname{ageC}_{i k}+F_{i}\left(\operatorname{dim}_{t}\right)+\sum_{l=0}^{2} \alpha_{i l p} z_{l}\left(\operatorname{dim}_{t}\right) \\
& +\sum_{l=0}^{2} \beta_{i l q} z_{l}\left(\operatorname{dim}_{t}\right)+\sum_{l=0}^{2} \gamma_{i l q} z_{l}\left(\operatorname{dim}_{t}\right)+\sum_{m=1}^{3} \delta_{i m} w_{m}\left(d P_{t}\right)+\varepsilon_{i j k p q t},
\end{aligned}
$$

where $H T D_{i j}$ was the $j$ th herd-test-date fixed effect for a trait $i$ (milk yield, fat and protein contents, 212 spectral points); age $C_{i k}$ was the fixed effects of the $k$ th class of age at calving; $F_{i}\left(d i m_{t}\right)$ was a function of the DIM associated with the record $t$, defined below; $\alpha_{i l p}$ was the $l$ th random regression coefficient for the herd $p ; \beta_{i l q}$ was the $l$ th random regression coefficient for the permanent environmental effect of animal $q ; \gamma_{i l q}$ was the $l$ th random regression coefficient for the additive genetic effect of animal $q ; z_{l}\left(\operatorname{dim}_{t}\right)$ was the $l$ th modified Legendre polynomial for the DIM associated with record $t$; $\delta_{i m}$ was the $m$ th coefficient of a cubic function for the regression on the number of $\mathrm{dP} w_{m}\left(d P_{t}\right)$, which allows to introduce the fixed effect of the pregnancy stage; and $\varepsilon_{i j k p q t}$ was the residual effect. Age at calving ranged from 21 to $46 \mathrm{mo}$, and 6 equal-sized classes were created using the PROC RANK procedure (SAS Institute Inc., Cary, NC). The cubic function on $\mathrm{dP}$ was chosen after a preliminary study assessed the equivalence between this function and a model with classes of $\mathrm{dP}$. All dP equal to zero corresponded to the nonpregnant status of dairy cows. The function has the advantage to smooth the pregnancy status effect on $\mathrm{dP}$ and, therefore, allows 
a better understanding of the evolution of the effect of the pregnancy status according to the pregnancy stage. Modified Legendre polynomial coefficients were computed as follows (Gengler et al., 1999):

$$
\begin{gathered}
z_{o}\left(\operatorname{dim}_{t}\right)=1, \\
z_{1}\left(\operatorname{dim}_{t}\right)=\sqrt{3} \times x_{t}, \text { and } \\
z_{2}\left(\operatorname{dim}_{t}\right)=\sqrt{5} / 4 \times\left(3 x_{t}^{2}-1\right),
\end{gathered}
$$

where $x_{t}=-1+2\left[\left(\operatorname{dim}_{t}-5\right) /(365-5)\right]$.

The rationale to use a function of DIM, $F_{i}\left(\operatorname{dim}_{t}\right)$, was to obtain the best possible lactation curve adjustments avoiding confounding with pregnancy effects. Based on literature the polynomial function as defined by Ali and Schaeffer (1987) was used:

$$
F_{i}\left(\operatorname{dim}_{t}\right)=a_{i}+b_{i} \mu_{t}+c_{i} \mu_{t}^{2}+d_{i} \rho_{t}+e_{i} \rho_{t}^{2},
$$

where [2] replaced in [1] $F_{i}\left(\operatorname{dim}_{t}\right)$, where for each trait $i$ (milk yield, fat, and protein contents, and 212 spectral points) $\operatorname{dim}_{t}$ was the DIM associated with the record $t$; $a, b, c, d$, and $e$ were the coefficients of the function; $\mu_{t}=\operatorname{dim}_{t} / 305 ;$ and $\rho_{t}=\ln \left(305 / d i m_{t}\right)$. The original definitions of $\mu_{t}$ and $\rho_{t}$ were used, but it can be shown that 305 is only a scaling factor and could be replaced by 365 or another constant. To assess if this function fitted correctly the observed lactation curves, it was fitted on milk yield, fat, and protein contents using the PROC GLM procedure (SAS Institute Inc.) using this model $y_{i t}=F_{i}\left(\operatorname{dim}_{t}\right)+e_{i t}$, where $F_{i}\left(\operatorname{dim}_{t}\right)$ was defined as in [2], $y_{i t}$ was for trait $i$ the record $t$, and $e_{i t}$ was the corresponding residual effect. Using the obtained coefficients, lactation curves were predicted and then compared with the observed averages of milk production traits per DIM.

An alternative matrix notation of [1] is

$$
\begin{gathered}
\mathbf{y}=\mathbf{T t}+\mathbf{C c}+\mathbf{F f}+\mathbf{Q}(\mathbf{H a}+\mathbf{Z b}+\mathbf{Z g}) \\
+\mathbf{W d}+\mathbf{e},
\end{gathered}
$$

where $\mathbf{y}$ was the vector of observation; $\mathbf{t}, \mathbf{c}$, and $\mathbf{f}$ were vectors for fixed effects for herd-test-day, calving age, and lactation stage (Ali and Schaeffer coefficients), respectively, $\mathbf{T}, \mathbf{C}$, and $\mathbf{F}$ being their respective incidence matrices linking them to $\mathbf{y}$; $\mathbf{Q}$ was a matrix of modified Legendre polynomial for the DIM associated with each record; $\mathbf{a}, \mathbf{b}$, and $\mathbf{g}$ were vectors of random regression coefficients for herd, permanent environment, and ge- netic effects, respectively; $\mathbf{H}$ and $\mathbf{Z}$ being the incidence matrices for $\mathbf{a}$ and $\mathbf{b}$ and $\mathbf{g}$, respectively, linking effects to random regressions for each records; $\mathbf{d}$ was the vector of fixed regression coefficients of functions of dP; $\mathbf{W}$ was the matrix of regression variables defined as linear, quadratic, and cubic functions of dP; and e was the vector random residuals. Expectations $(E)$ and variance of $\mathbf{y}$ and random effects were

$E(\mathbf{y})=\mathbf{T} \mathbf{t}+\mathbf{C c}+\mathbf{F} \mathbf{f}+\mathbf{W d}$ and
$\operatorname{Var}\left[\begin{array}{c}\mathbf{y} \\ \mathbf{a} \\ \mathbf{b} \\ \mathbf{g} \\ \mathbf{e}\end{array}\right]=\left[\begin{array}{ccccc}\mathbf{Q}\left(\mathbf{H G}_{a} \mathbf{H}^{\prime}+\mathbf{Z G}_{b} \mathbf{Z}^{\prime}+\mathbf{Z G}_{g} \mathbf{Z}^{\prime}\right) \mathbf{Q}^{\prime}+\mathbf{R} & \mathbf{Q H G}_{a} & \mathbf{Q Z G}_{b} & \mathbf{Q Z G}_{g} & \mathbf{R} \\ \mathbf{G}_{a} \mathbf{H}^{\prime} \mathbf{Q}^{\prime} & \mathbf{G}_{a} & \mathbf{0} & \mathbf{0} & \mathbf{0} \\ \mathbf{G}_{b} \mathbf{Z}^{\prime} \mathbf{Q}^{\prime} & \mathbf{0} & \mathbf{G}_{b} & \mathbf{0} & \mathbf{0} \\ \mathbf{G}_{g} \mathbf{Z}^{\prime} \mathbf{Q}^{\prime} & \mathbf{0} & \mathbf{0} & \mathbf{G}_{g} & \mathbf{0} \\ \mathbf{R} & \mathbf{0} & \mathbf{0} & \mathbf{0} & \mathbf{R}\end{array}\right]$,

under the hypothesis that regressions are ordered inside herds and animals, respectively,

$$
\begin{gathered}
\mathbf{G}_{a}=\mathbf{I}_{a} \otimes\left[\begin{array}{ccc}
\sigma_{a_{0}}^{2} & \sigma_{a_{0}, a_{1}} & \sigma_{a_{0}, a_{2}} \\
\sigma_{a_{1}, a_{0}} & \sigma_{a_{1}}^{2} & \sigma_{a_{1}, a_{2}} \\
\sigma_{a_{2}, a_{0}} & \sigma_{a_{2}, a_{1}} & \sigma_{a_{2}}^{2}
\end{array}\right], \\
\mathbf{G}_{b}=\mathbf{I}_{b} \otimes\left[\begin{array}{ccc}
\sigma_{b_{0}}^{2} & \sigma_{b_{0}, b_{1}} & \sigma_{b_{0}, b_{2}} \\
\sigma_{b_{1}, b_{0}} & \sigma_{b_{1}}^{2} & \sigma_{b_{1}, b_{2}} \\
\sigma_{b_{2}, b_{0}} & \sigma_{b_{2}, b_{1}} & \sigma_{b_{2}}^{2}
\end{array}\right], \text { and } \\
\mathbf{G}_{g}=\mathbf{A} \otimes\left[\begin{array}{ccc}
\sigma_{g_{0}}^{2} & \sigma_{g_{0}, g_{1}} & \sigma_{g_{0}, g_{2}} \\
\sigma_{g_{1}, g_{0}} & \sigma_{g_{1}}^{2} & \sigma_{g_{1}, g_{2}} \\
\sigma_{g_{2}, g_{0}} & \sigma_{g_{2}, g_{1}} & \sigma_{g_{2}}^{2}
\end{array}\right],
\end{gathered}
$$

with $\mathbf{I}_{a}$ and $\mathbf{I}_{b}$ being identity matrices representing the number of herds and the number of animals, respectively; A being the numerator relationship matrix between animals; and the $3 \times 3$ matrices representing the variances associated with constant, linear, and quadratic modified Legendre polynomials (on the diagonal) and the covariances among them (off diagonal). Residual variances were considered lactation stage-independent, $\operatorname{Var}(\mathbf{e})=\mathbf{R}=\mathbf{I} \sigma_{e}^{2}$. As outlined by Gengler and Wiggans (2001), this can be defended, as the model contains several other environmental random effects that are lactation stage-dependent. Extracting covariances between residuals and variance differences among residuals and putting these into additional random effects was a straightforward application of basic mixed 
model theory, as described by several authors (e.g., Robinson, 1991).

Model [1] was applied on milk yield, fat, and protein contents and each of the 212 selected spectral points independently, similar to Bittante and Cecchinato (2013), who performed a genetic analysis and estimated the variance components of MIR spectra of bovine milk. Variance components were estimated using the restricted maximum likelihood algorithm implemented in the REMLF90 program (Misztal, 2012), also providing solutions for fixed and random effects.

\section{Effect of Pregnancy Status}

To allow comparisons (with a common unit) among the traits, for each trait (milk yield, fat, and protein content, and the 212 spectral points), solutions of coefficients for $\mathrm{dP}$ were extracted and normalized by dividing them by the square-root of the estimated averaged phenotypic variance from 5 to 365 DIM. Phenotypic variances at a given DIM were calculated as the sum of the residual variance, the genetic variance, the variance of the herd, and the permanent environmental variance of the considered trait at this DIM. The effect of the pregnancy stage on a given trait was therefore expressed as a relative effect, making comparisons between traits possible. The standard error (SE) of the effect of pregnancy was approximated for every trait i at each $\mathrm{dP}$ using

$$
\sum_{m=1}^{3} \mathrm{SE}_{\delta_{i m}} w_{m}\left(d P_{t}\right)
$$

to obtain the weighted sum of the individual SE of each coefficient $\delta$ obtained for every trait $i$ and each function $\mathrm{m}$ (linear, quadratic, and cubic) of $\mathrm{dP}$.

\section{RESULTS AND DISCUSSION}

\section{Data Distribution and Lactation Curve}

Proportion of pregnant (51\%) and nonpregnant (49\%) status were almost evenly represented among TD records of our data set. Distribution of successful inseminations started at 24 DIM; on average, insemination succeeded at $129( \pm 65)$ DIM. Figure 1 shows the distribution of TD records by stage of lactation according to their pregnancy status (pregnant vs. nonpregnant). On each DIM, on average, $158( \pm 38)$ TD records were available. From 90 to 180 DIM, the number of TD records belonging to each pregnancy status was quite similar, with 7,873 and 8,124 observations for pregnant and nonpregnant status with an average of 93 and 82 records per DIM, respectively. Records from nonpregnant cows with a higher stage of lactation are probably from cows that were not (re-)inseminated because of fertility or health issues. The number of TD records belonging to pregnant cows slightly decreased after 275 DIM due to the dry off period (e.g., 1 or 2 mo before next calving in Wallonia) and due to the calving intervals for Holstein cows between first and second lactation, which was, on average, $418 \mathrm{~d}$ in our data set.

In Figure 2 the observed lactation curve and the lactation curve estimated with Ali and Schaeffer (1987) function are both presented for milk yield, fat, and protein contents. The coefficients of determination of

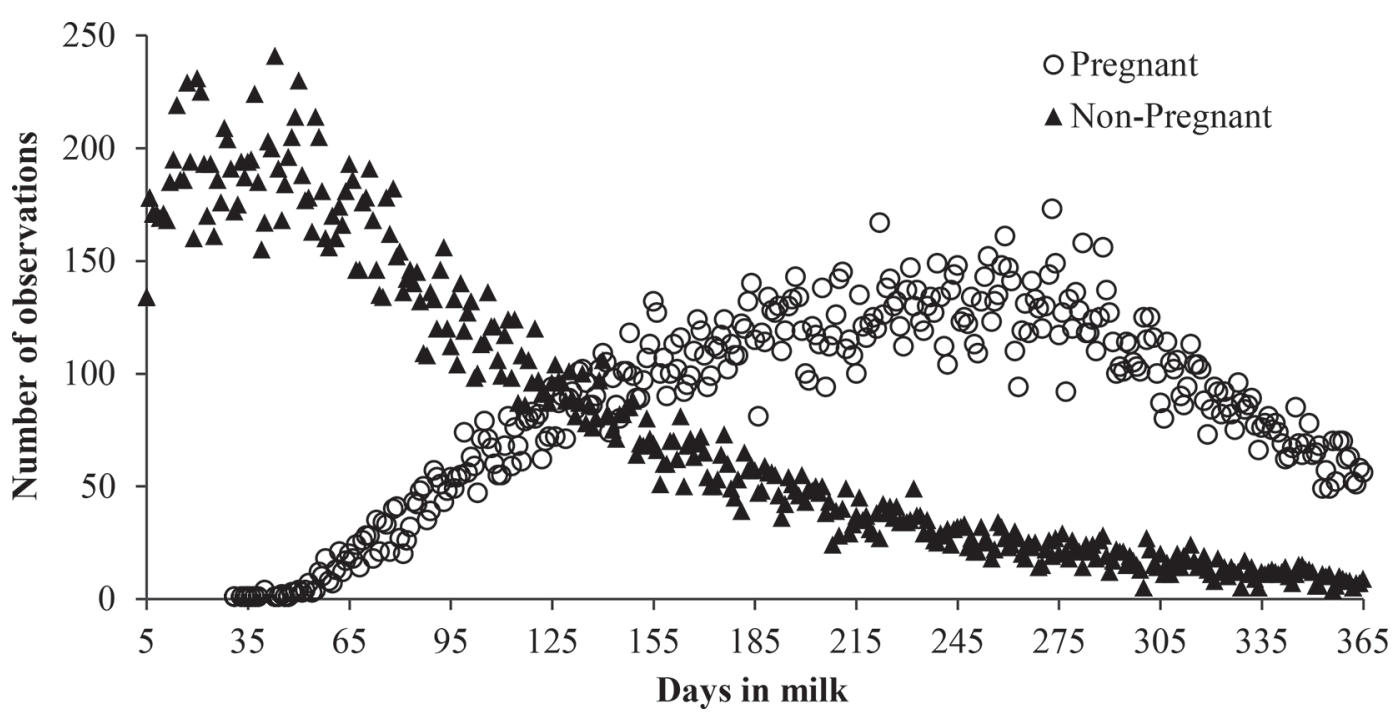

Figure 1. Distribution of test days by groups of pregnancy status (pregnant and nonpregnant) along the stage of lactation for first-parity Holstein cows. 
these functions were $0.968,0.939$, and 0.980 for milk yield, fat, and protein contents, respectively. This demonstrated that the use of this function to estimate the stage of lactation effect fit the observed effect of lactation curve on milk yield, fat, and protein contents very well. The same function was tested on several spectral points and showed similar results (results not shown); this was expected, as fat and protein contents are predicted as linear combinations of spectral traits. The Ali and Schaeffer function was also tested by Silvestre et al. (2006) under different conditions of data availability and showed good performances if the number of TD records per lactation was sufficient. Silvestre et al. (2006) demonstrated that daily records provided the best results, but also showed good results with $11 \mathrm{TD}$ records per lactation and an interval of $4 \mathrm{wk}$ between TD. In the present study, the average number of TD records per lactation was of $6( \pm 3)$ with an interval of 4 wk between tests. However, this is less relevant in our study, as we fitted the function on all available records simultaneously.

\section{Effect of Pregnancy Stage on Milk Production Traits}

The average phenotypic variances of milk yield, fat, and protein contents were $13.92\left(\mathrm{~kg}^{2}\right), 26.06$, and 5.95 $\left(\mathrm{g}^{2} / \mathrm{kg}^{2}\right)$, respectively. Figure 3 shows the relative effect of dP on milk yield, fat, and protein contents. The evolution of the relative effect of pregnancy according to the $\mathrm{dP}$ was very consistent with previous studies (Olori et al., 1997; Bohmanova et al., 2009; Loker et al., 2009; Penasa et al., 2016). In their model with a regression on $\mathrm{dP}$ to account for the pregnancy effect, Bohmanova et al. (2009) observed a slight decrease in milk yield during the first 4 mo of pregnancy $(120 \mathrm{dP})$ and then a stronger decrease. Loker et al. (2009) reported that milk yield started to decrease significantly after $120 \mathrm{dP}$. In the current study, we also observed an important decrease in milk yield at around $120 \mathrm{dP}$ (Figure 3). Olori et al. (1997) described an increase of fat content and an increase of protein content from $150 \mathrm{dP}$ with a stronger increase for fat content than for protein content. In the present study, the fat content started to increase at around $120 \mathrm{dP}$ (Figure 3). Table 1 presents some key values of the relative effect (in absolute value) of pregnancy on the milk production traits (milk yield, fat, and protein contents) at different $\mathrm{dP}$. The relative effect of pregnancy on milk yield is always higher than the relative effect of pregnancy on fat and protein contents. The loss in milk yield and the increase in later $\mathrm{dP}$ in fat and protein contents according to the $\mathrm{dP}$ are also presented in Table 1. Olori et al. (1997) mentioned that milk yield of cows at $240 \mathrm{dP}$ had a loss of $3 \mathrm{~kg}$ of milk compared with nonpregnant cows, and a loss of around $0.5 \mathrm{~kg}$ of milk for cows at $120 \mathrm{dP}$. Using a model with regression on $\mathrm{dP}$, Bohmanova et al. (2009) estimated a loss of $0.5,0.8$, and $3 \mathrm{~kg}$ of milk for cows at 120, 150, and $210 \mathrm{dP}$, respectively, compared with nonpregnant cows. These results on the loss of milk yield according to the pregnancy stage compared with nonpregnant cows are similar to results in our study (Table 1). Loker et al. (2009) observed a loss of $1 \mathrm{~kg}$ of milk for firstparity Ayrshire dairy cows at $60 \mathrm{dP}$ and a loss of $4 \mathrm{~kg}$ of milk for pregnant cows at $210 \mathrm{dP}$ compared with



Figure 2. Average lactation curves (dots) within the whole data set for milk yield and fat and protein contents, and lactation curves estimated (solid lines) with the Ali and Schaeffer (1997) function of the DIM for first-parity Holstein cows. 
nonpregnant cows. In our study, we observed slightly lower loss of milk for pregnant Holstein cows at 60 and $210 \mathrm{dP}, 0.3$ and $0.5 \mathrm{~kg}$, respectively. Olori et al. (1997) also studied the effect of the pregnancy stage on fat and protein contents and found an increase in fat content of $1 \mathrm{~g} / \mathrm{kg}$ higher for pregnant cows at $210 \mathrm{dP}$, whereas we had an increase of $1.8 \mathrm{~g} / \mathrm{kg}$ at $210 \mathrm{dP}$ compared with nonpregnant cows (Table 1). However, the patterns of the increase in fat content between the 2 studies are similar, with a slight decrease in the beginning of the pregnancy and an increase from $150 \mathrm{dP}$ (Figure 3; Table 1). The patterns for protein contents (i.e., slight increase in protein content of pregnant cow at the beginning of the pregnancy, then a decrease, and then a slight increase at the end of the pregnancy; Figure 3; Table 1) were also observed by Olori et al. (1997), with a protein content higher of $0.2 \mathrm{~g} / \mathrm{kg}$ for pregnant cows at $240 \mathrm{dP}$ compared with nonpregnant cows. Given the complexity of this type of study, comparisons between them should consider differences in data sets and models. Olori et al. (1997) studied the effect of pregnancy stage on only 448 first-parity cows, whereas we had a higher number of first-parity cows $(9,757)$ milked twice a day and recorded more recently. This may explain the slight differences observed on fat and protein contents; however, the effect of pregnancy stage on milk yield and the patterns of the effect of pregnancy on fat and protein contents were consistent with previous studies and demonstrated that our model accounted well for the pregnancy stage.

Preliminary results (not shown) demonstrated the equivalence between a cubic function of $\mathrm{dP}$ and a model with classes of dP. Previous studies by other authors mainly used models with classes of month of pregnancy or number of days pregnant to account for the pregnancy effect. Penasa et al. (2016) used a model with 4 classes to assess the pregnancy effect (not pregnant, 1-120 dP, 121-210 dP, >211 dP), and the best model
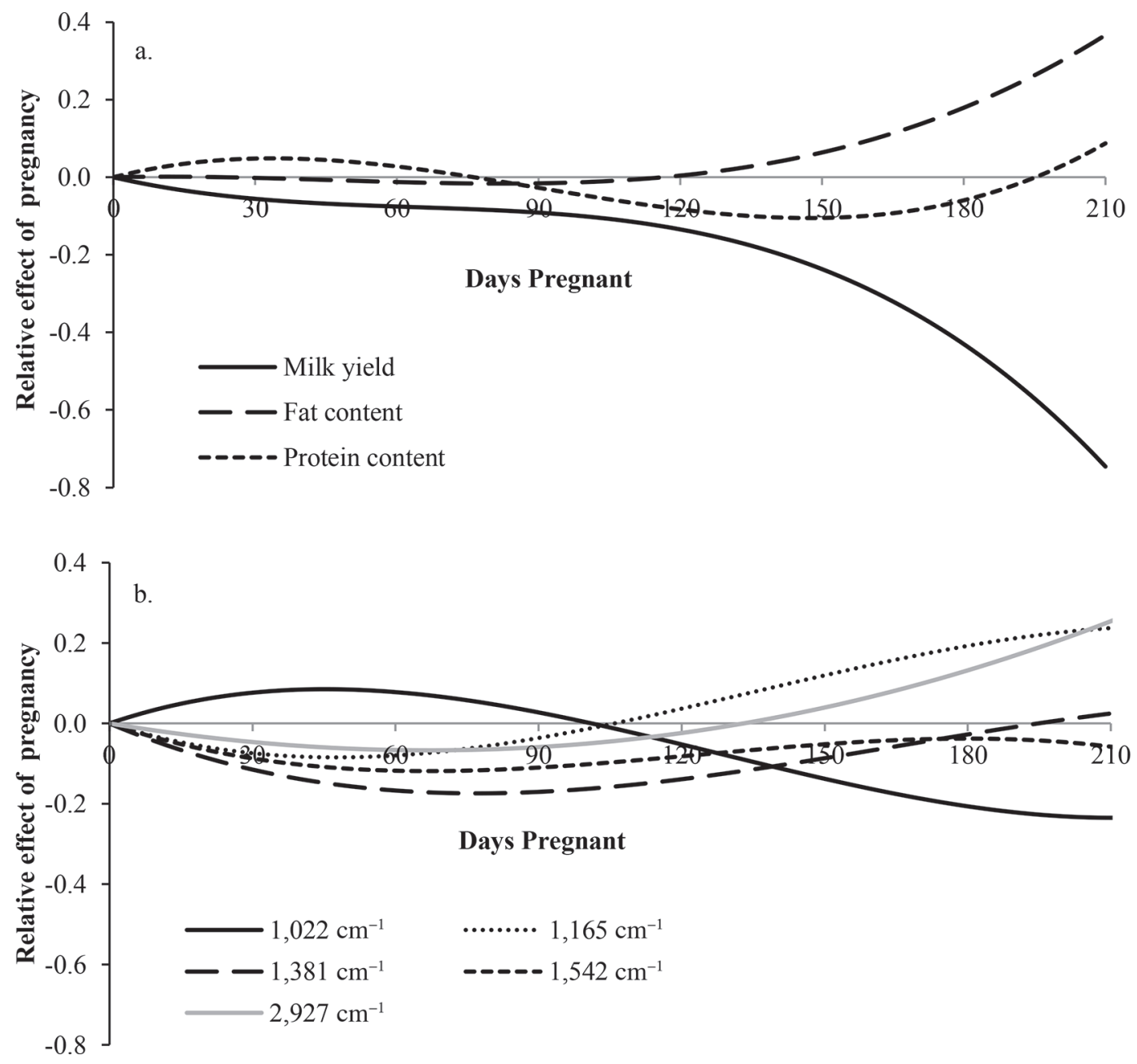

Figure 3. Evolution of the relative effect of the pregnancy status on (a) milk yield and fat and protein contents and on (b) some specific wavenumbers with the numbers of days pregnant $(\mathrm{dP})$, where $\mathrm{dP}=0$ is for nonpregnant status. 
Table 1. Distribution of the relative effect of the pregnancy (in absolute value) on milk yield, fat, and protein content at different days pregnant $(\mathrm{dP})$ and loss $(<0)$ or gain $(>0)$ in milk yield $(\mathrm{kg})$, fat, and protein content $(\mathrm{g} / \mathrm{kg})$ at different $\mathrm{dP}$

\begin{tabular}{|c|c|c|c|c|c|c|c|c|c|}
\hline \multirow[b]{2}{*}{$\mathrm{dP}$} & \multicolumn{3}{|c|}{ Milk yield } & \multicolumn{3}{|c|}{ Fat content } & \multicolumn{3}{|c|}{ Protein content } \\
\hline & $\mathrm{kg}$ & Relative effect & $\mathrm{SE}^{1}$ & $\mathrm{~g} / \mathrm{kg}$ & Relative effect & $\mathrm{SE}^{1}$ & $\mathrm{~g} / \mathrm{kg}$ & Relative effect & $\mathrm{SE}^{1}$ \\
\hline 60 & -0.282 & 0.075 & 0.040 & -0.062 & 0.012 & 0.043 & 0.068 & 0.028 & 0.036 \\
\hline 90 & -0.340 & 0.091 & 0.076 & -0.080 & 0.016 & 0.082 & -0.066 & 0.027 & 0.069 \\
\hline 120 & -0.502 & 0.134 & 0.125 & 0.022 & 0.004 & 0.136 & -0.202 & 0.083 & 0.114 \\
\hline 150 & -0.884 & 0.237 & 0.189 & 0.326 & 0.064 & 0.207 & -0.256 & 0.105 & 0.173 \\
\hline
\end{tabular}

${ }^{1} \mathrm{SE}=$ approximate $\mathrm{SE}$ of the relative effect.

in Loker et al. (2009) included 8 classes of pregnancy. However, Loker et al. (2009) also mentioned that the model with a regression on $\mathrm{dP}$ had similar performances than with classes of pregnancy. Bohmanova et al. (2009) concluded that a model with classes of month of pregnancy and a model with regression on the $\mathrm{dP}$, to account for the pregnancy effect within the Canadian test-day model, performed similarly. In the current study, we considered using a model with regression on $\mathrm{dP}$, and not with classes of $\mathrm{dP}$, as a better option to fit the estimated effect of the stage of pregnancy on milk production traits and on MIR spectra (212 spectral points). Results of our model on milk production traits (milk yield, fat, and protein contents) were very similar to previous studies that used either models with classes of $\mathrm{dP}$ or models with a regression on $\mathrm{dP}$ (Olori et al., 1997; Bohmanova et al., 2009; Loker et al., 2009; Penasa et al., 2016).

\section{Genetic Parameters Within the Model on MIR Spectra}

The phenotypic variance explained by the model for each of the 212 spectral points had a wide range of variability, from 0.99 to 287.00 with an average value of $25.66( \pm 55.52)$. The highest variances estimates were located in the 1,732 to 1,763 and 2,831 to $2,966 \mathrm{~cm}^{-1}$ regions of the MIR spectrum. Figure 4 represents the percentage of the total variation explained within the model by the genetic, permanent environment, herd, and residual effects. On average, the total variation of MIR wavenumbers by genetic, permanent environment, and herd effects was 33, 10 and $33 \%$, respectively, whereas the residual effect explained $24 \%$ of the total variation. Lowest proportions of variation explained by the genetic effect were observed around $1,800 \mathrm{~cm}^{-1}$ and from 1,300 to $1,400 \mathrm{~cm}^{-1}$ (Figure 4). In their study, Wang et al. (2016) also observed a low percentage of

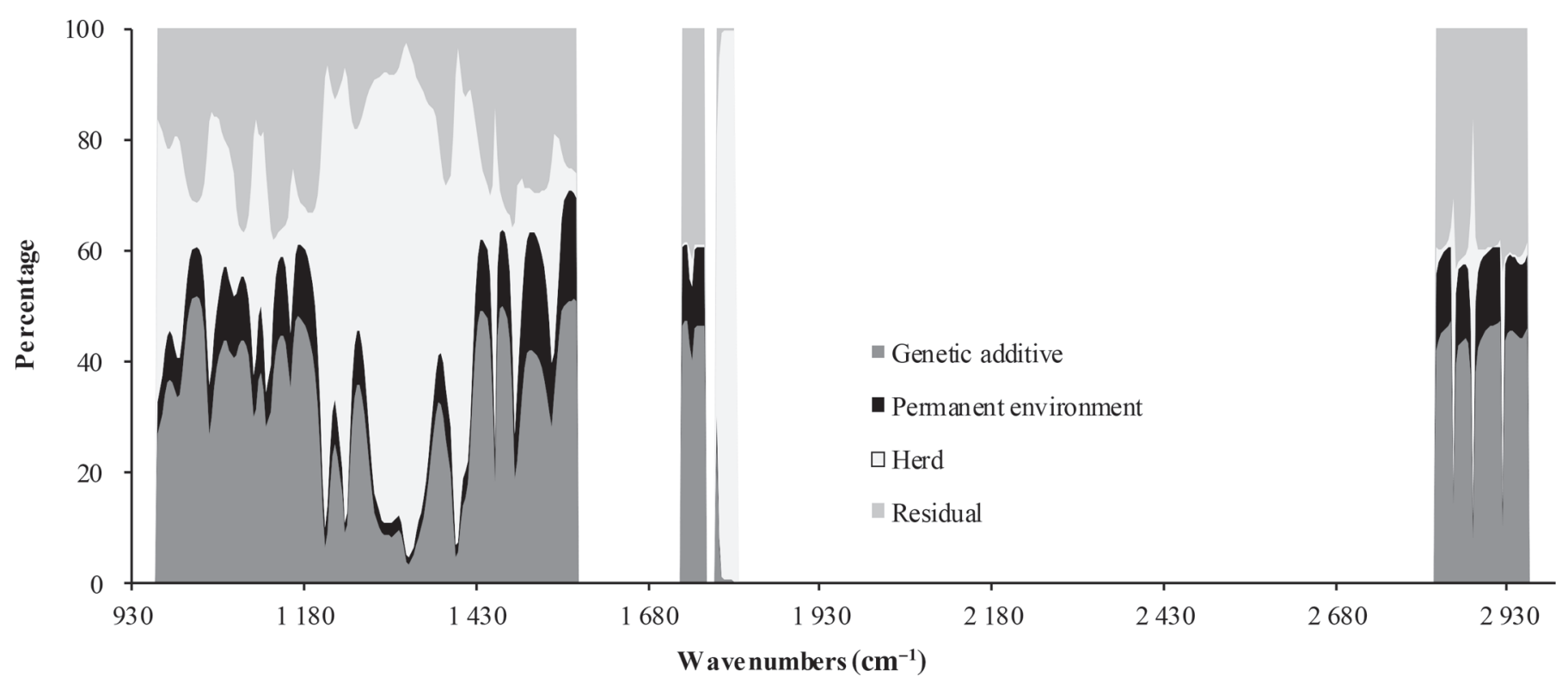

Figure 4. Percentage of the total variation of mid-infrared wavenumbers explained by genetic, permanent environment, herd, and residual effects. 
the total variation of MIR wavenumbers explained by the genetic effect from 1,200 to $1,525 \mathrm{~cm}^{-1}$, even though their model was different from the present model. Figure 4 depicted a wide variability regarding wavenumbers which has to be further investigated.

\section{Effect of Pregnancy Stage on the MIR Spectra}

General Overview of the Effect of Pregnancy on MIR Spectra. The relative effect of the pregnancy status on the MIR spectrum (212 spectral points) for some $\mathrm{dP}$ is presented on Figure 5. Within the MIR spectrum of milk, the effect of the pregnancy stage is not constant and varies according to the wavenumbers. As expected the relative effect of the pregnancy stage on the MIR spectrum, and therefore on the milk composition, becomes, in absolute value, generally more important later in pregnancy (higher $\mathrm{dP}$ values). For some specific MIR spectral regions, results suggested that the relative effect of the pregnancy was more important on them than on milk production traits (milk yield, fat, and protein contents). Figure 6 presents the

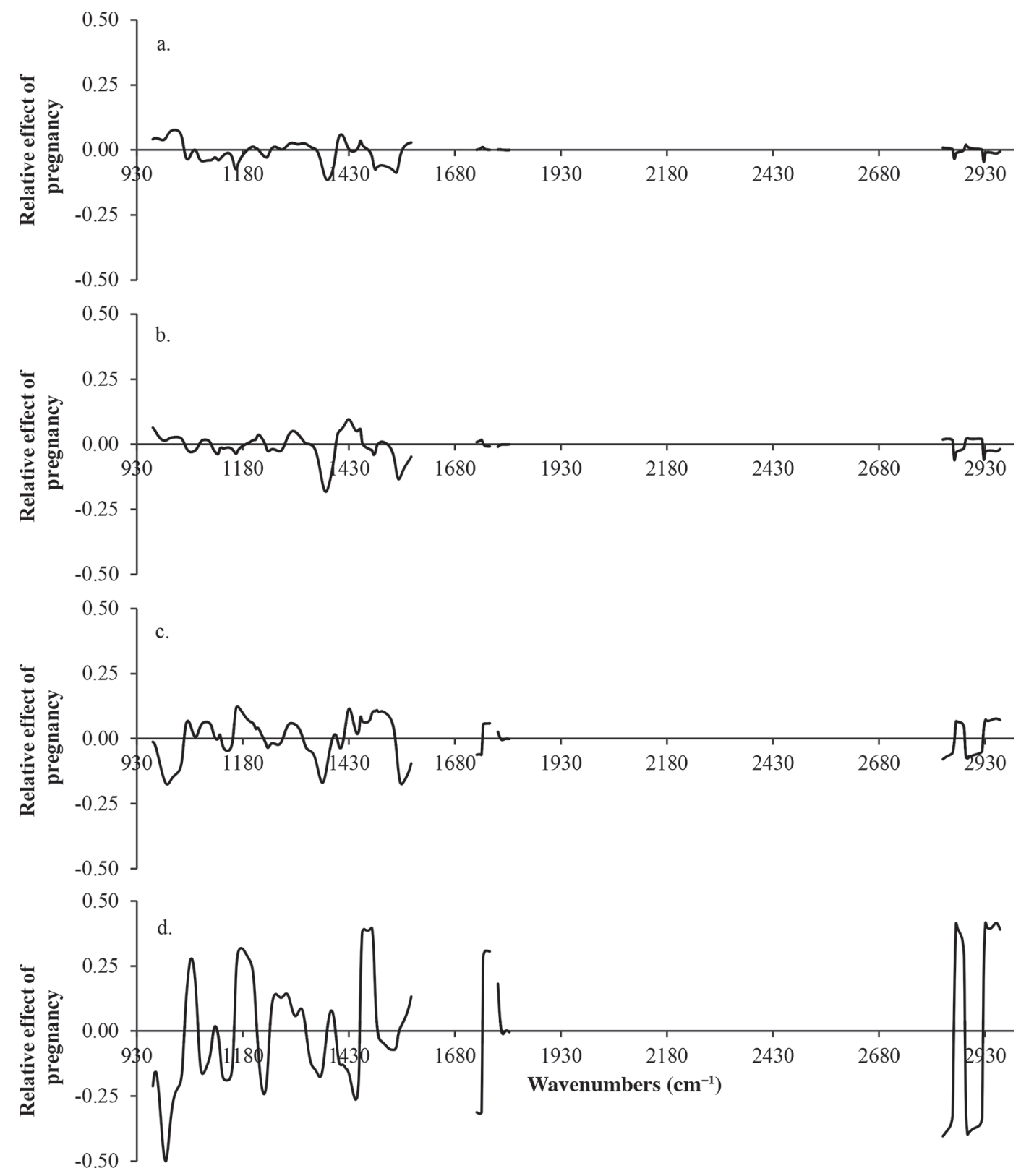

Figure 5. Relative effect of the pregnancy status at (a) $30 \mathrm{~d}$ pregnant (dP), (b) $90 \mathrm{dP}$, (c) $150 \mathrm{dP}$, and at (d) $210 \mathrm{dP}$ on the $212 \mathrm{spectral}$ points of the milk mid-infrared spectra. 


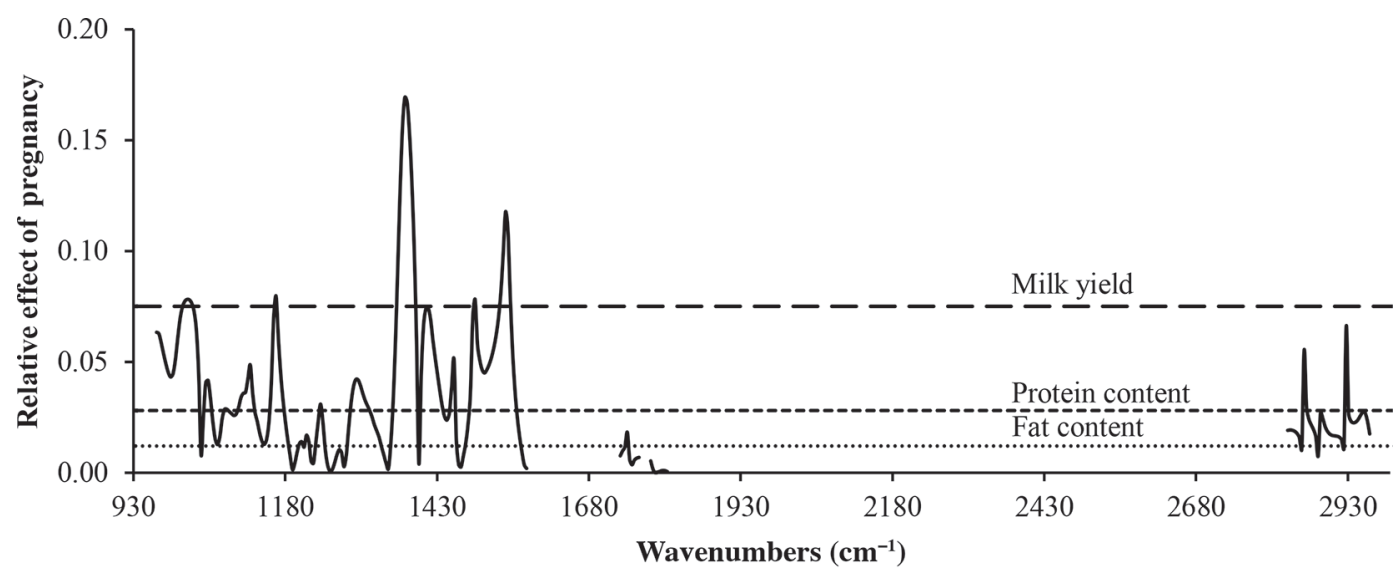

Figure 6. Relative effect of the pregnancy status at $60 \mathrm{~d}$ pregnant expressed in absolute value on the milk mid-infrared spectra compared with the effect of the pregnancy status at $60 \mathrm{~d}$ pregnant on milk yield, on protein content, and on fat content.

relative effect of the pregnancy status in absolute value at $60 \mathrm{dP}$. The relative effect of the pregnancy status at $60 \mathrm{dP}$ on milk production traits is also represented. We can clearly observe that, for some specific wavenumbers, relative effect of the pregnancy status at $60 \mathrm{dP}$ is higher than on fat content, on protein content, and also on milk yield. As predicted fat and protein contents are linear combinations of the MIR spectrum, it was expected that some wavenumbers were reacting stronger than those milk components, which might tend to average out the effect of pregnancy. The relative effect of pregnancy on several specific wavenumbers is shown in Figure 3. It allows comparing the effect of pregnancy on these wavenumbers with the effect on milk production traits at different stages of pregnancy. The specific wavenumbers given in Figure 3 were chosen based on their highest value for the relative effect of pregnancy early in the pregnancy stage (from 30 to $90 \mathrm{dP}$ ). The evolutions of the effect on wavenumbers along the pregnancy stage are not constant and change with the stage of pregnancy, getting higher in late pregnancy.

Effect on Wavenumbers and Comparisons with Milk Parameters. Linking reaction to pregnancy detected in MIR spectra and milk composition is not easy. Table 2 presents the relative effect (in absolute value) of pregnancy at different $\mathrm{dP}$ for some of the main chemical bonds of milk components having a response in MIR. The stretching vibration of $\mathrm{C}-\mathrm{O}$ from alcohols functions and of $\mathrm{C}-\mathrm{O}-\mathrm{C}$ ether aromatic functions, which are chemical bonds specific to the lactose molecule (Grelet et al., 2015), were less affected by pregnancy stage than milk yield. At $60 \mathrm{dP}$, the relative effect of pregnancy on milk yield was 0.075 (Table 1 ), whereas it was 0.025 and 0.001 for $\mathrm{C}-\mathrm{O}$ and $\mathrm{C}-\mathrm{O}-\mathrm{C}$, respectively. After 150 $\mathrm{dP}$, the relative effect of pregnancy was still more important for milk yield, fat, and protein contents (Table
1) than for the response of the $\mathrm{C}-\mathrm{O}$ and $\mathrm{C}-\mathrm{O}-\mathrm{C}$ stretching vibration. The effect of pregnancy on stretching and bending of the $\mathrm{C}-\mathrm{H}$ bonds were more important in the beginning of the pregnancy than on fat and protein contents (Table 1). At $60 \mathrm{dP}$, the relative effect of pregnancy on the stretching of $\mathrm{C}-\mathrm{H}_{2}\left(2,927 \mathrm{~cm}^{-1}\right)$ and $\mathrm{C}-\mathrm{H}_{3}$ $\left(2,862 \mathrm{~cm}^{-1}\right)$ was 0.066 and 0.030 , respectively, whereas it was 0.012 for fat content (Table 1). These peaks of absorption are specific to fat chains (Soyeurt et al., 2006; Grelet et al., 2015), and according to these results they seems to be more affected by the pregnancy than the fat content at an early stage of pregnancy. Chemical bonds that include nitrogen molecules (i.e., C-N, $\mathrm{N}-\mathrm{N}$ ) are specific to protein, and the stretching of such bonds was reported to induce a response around 1,550 $\mathrm{cm}^{-1}$ (Bonfatti et al., 2011; Grelet et al., 2015). The relative effect of pregnancy at $60 \mathrm{dP}$ on this specific wavenumber was higher (Table 2) than the relative effect of pregnancy at $60 \mathrm{dP}$ on the protein content itself (Table 1). This indicates again that the raw spectral information is potentially more informative than linear combinations of its components, as in the case of the protein content.

Effect of Pregnancy on Milk Parameters and on MIR Spectral Region. The MIR region located between 968 and $1,577 \mathrm{~cm}^{-1}$ is often called the fingerprint of milk region because of the $\mathrm{C}-\mathrm{O}$ and $\mathrm{C}-\mathrm{C}$ stretching modes (Soyeurt et al., 2010). The average relative effect of pregnancy was higher in this MIR region than on the fat content at $30,60,90$, and 120 $\mathrm{dP}$, and higher than on the protein content at 60 and $90 \mathrm{dP}$ (Table 3). Highest values of the relative effect of pregnancy on MIR spectra were observed in this MIR spectral region and were higher than on fat and protein content, but also higher than on milk yield. This can also be observed on the Figure 5, where the relative 
effect of the pregnancy status (in absolute value) at a stage of $60 \mathrm{dP}$ is shown and compared with the relative effect of the pregnancy status at the same stage on milk production traits. The highest values within this MIR spectral region for the relative effect of pregnancy were observed between 1,377 and $1,381 \mathrm{~cm}^{-1}$ at the beginning of the pregnancy and between 999 and $1,003 \mathrm{~cm}^{-1}$ after $150 \mathrm{dP}$ (Table 3). According to Soyeurt et al. (2010), carboxylic groups of protein induce a response between 1,200 and $1,450 \mathrm{~cm}^{-1}$. Moreover, stretching mode of $\mathrm{N}-\mathrm{O}$ and $\mathrm{NO}_{2}$ also induce a response around $1,375 \mathrm{~cm}^{-1}$ (Socrates, 1980), which could be related to pregnancy-associated proteins. Socrates (1980) also mentioned that around $1,375 \mathrm{~cm}^{-1}$ carbon chains and $\mathrm{C}$ $=\mathrm{O}$ bonds, linked to FA, induce a response. On average, the lowest values of the relative effect of pregnancy on MIR spectra were observed within the intervals from 1,732 to $1,763 \mathrm{~cm}^{-1}$ and from 1,782 to $1,809 \mathrm{~cm}^{-1}$ (Table 4). Highest values of the relative effect of pregnancy within these MIR spectral regions were in the same range as for fat content and were lower than protein content (Table 1). Soyeurt et al. (2006) mentioned that the spectral region located between 1,736 and 1,805 $\mathrm{cm}^{-1}$ is related to FA in cow milk. However, in this region it seems that the wavenumbers of MIR spectra of milk were not significantly affected by the pregnancy status (Table 4). Within the MIR spectral region from 2,831 to $2,966 \mathrm{~cm}^{-1}$, average values of the relative effect of pregnancy were higher than for fat content at 30,60, and $90 \mathrm{dP}$, but lower than for protein content (Table 5). However, the maximum values for the relative effect of pregnancy in this MIR spectral region were higher than the relative effect of pregnancy on fat content at all $\mathrm{dP}$, and they were higher than on protein content at 60, 90, 180, and $210 \mathrm{dP}$ (Table 5). Maximum values for the relative effect of pregnancy on MIR spectra within this MIR spectral region were observed to be around $2,927 \mathrm{~cm}^{-1}$ at 30 and $60 \mathrm{dP}$ and around $2,858 \mathrm{~cm}^{-1}$ at 90 and $120 \mathrm{dP}$ (Table 5). According to Bittante and Cecchinato (2013), these wavenumbers are related to the absorption of $\mathrm{C}-\mathrm{H}$ linkages that are involved in FA. Moreover, Soyeurt et al. (2006, 2010) mentioned that the region located between 2,800 and $3,000 \mathrm{~cm}^{-1}$ is also related to FA in cow milk. These specific wavenumbers related to FA seems to be more affected by the pregnancy status early in the lactation than the fat content itself (Table 5).

To our knowledge, the present study is the first investigations on the effect of pregnancy status on MIR spectra of bovine milk. However, results on the effect of pregnancy on MIR spectra are consistent with known patterns of the effect of pregnancy on bovine milk yield (Olori et al., 1997; Bohmanova et al., 2009; Loker et al., 2009; Penasa et al., 2016). Usually, MIR spectra of 
Table 3. Distribution of the mean with the SD, median, minimum, and maximum values of the relative effect of pregnancy (in absolute value) on spectral points within the MIR region from $968 \mathrm{~cm}^{-1}$ to $1,577 \mathrm{~cm}^{-1}$ at different days pregnant (dP) and comparisons with the relative effect of pregnancy (in absolute value) on milk yield and fat and protein contents

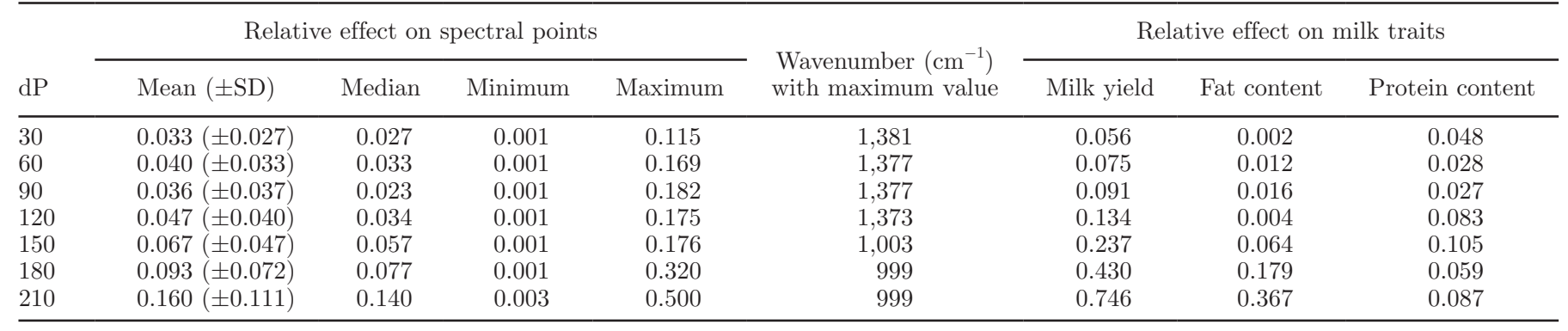

bovine milk are used to predict the milk composition using linear combinations of absorbance values. The range of predictions using MIR spectra is wide and not restrained to major milk components, such as fat and protein content, but also allows predictions of minor milk components (i.e., FA, minerals, and ketone bodies). Therefore, new linear combinations of absorbance value at given wavenumbers may aid in predictions of novel traits of interest, such as pregnancy status. The difficulty is to find these new linear combinations or ways to combine information present in the MIR spectra to determine novel traits of interest.

In this study, the effect of the pregnancy stage on the MIR spectra has been shown to be highly variable according to the MIR region. Whereas some wavenumbers were highly affected by the pregnancy status, some were not. This study also showed that, at the beginning of the pregnancy, for some specific wavenumbers of the milk MIR spectrum, the relative effect of pregnancy is higher than for milk yield, fat, and protein contents. Further studies are warranted to confirm these first results and to investigate the effect on multiparous cows, as this study only investigated first-parity cows. According to Loker et al. (2009), the effect of the pregnancy status is higher for cows in higher lactations (parity 2 and 3) on milk production traits. Therefore, we can assume that the effect of the pregnancy status on the
MIR spectra will also be higher for further parities, but this has yet to be investigated. If the reaction of milk composition to pregnancy is confirmed, additional research could explore novel opportunities for the use of FT-MIR technology in the management of pregnancy in dairy cows. Innovative use of this technology is recognized as a source of novel information and allows defining indirect traits describing animal status, health, and fertility (Egger-Danner et al., 2015). Finally, if this study addressed internal stress (i.e., pregnancy), Hammami et al. (2015) studied the use of reactions of milk components for a given individual cow to external stress (i.e., heat stress). The logical next step will be the use of these reactions as novel model-based biomarkers to study resilience of cows to external or internal stress.

\section{CONCLUSIONS}

Results showed that the effect of early pregnancy can be observed in the detailed milk composition through the analysis of the MIR spectrum of bovine milk. Further analyses are warranted to validate, but also to explore more deeply the potential and the required modeling strategies (e.g., reaction norms) to properly use the potential of MIR spectra of bovine milk in this context for breeding and management.

Table 4. Distribution of the mean with the SD, median, minimum, and maximum values of the relative effect of pregnancy (in absolute value) on spectral points within the mid-infrared region from 1,732 to $1,763 \mathrm{~cm}^{-1}$ and from 1,782 to $1,809 \mathrm{~cm}^{-1}$ at different days pregnant (dP) and comparisons with the relative effect of pregnancy (in absolute value) on milk yield and fat and protein contents

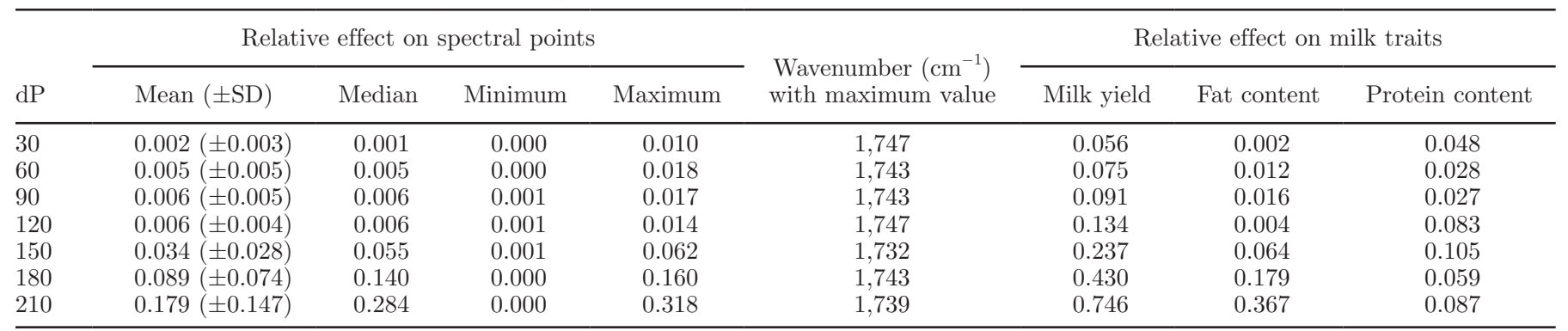


Table 5. Distribution of the mean with the SD, median, minimum, and maximum values of the relative effect of pregnancy (in absolute value) on spectral points within the mid-infrared region from 2,831 to $2,966 \mathrm{~cm}^{-1}$ at different days pregnant (dP) and comparisons with the relative effect of pregnancy (in absolute value) on milk yield and fat and protein contents

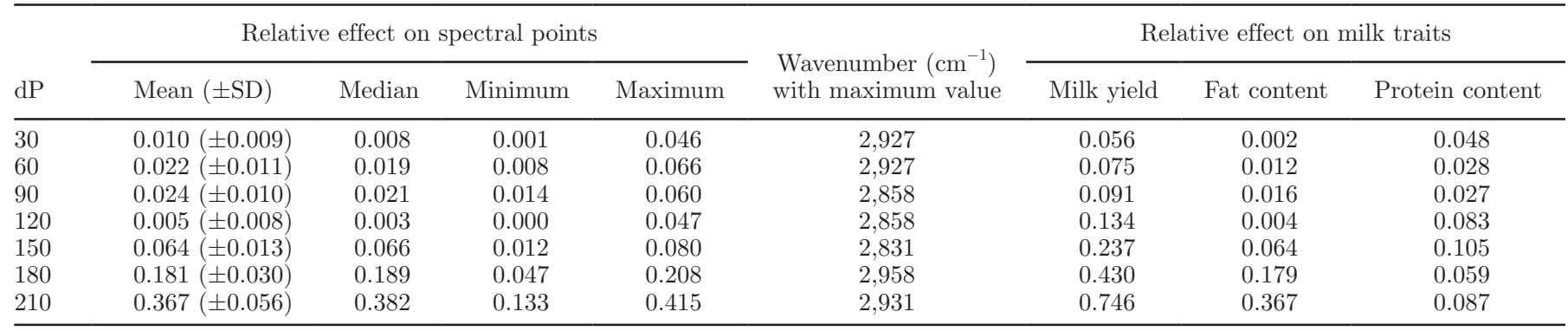

\section{ACKNOWLEDGMENTS}

The authors thank the INTERREG IVB NWE program (Lille, France) and the Ministry of Agriculture of the Walloon Region of Belgium (Service Public de Wallonie, Direction générale operationnelle "Agriculture, Ressources naturelles et Environnement"; DGO3, Namur, Belgium) for their financial support to the OptiMIR project (www.optimir.eu). The research leading to these results has also received funding from the European Union's Seventh Framework Programme for research, technological development and demonstration under grant agreement $n^{\circ} 613689$ (GplusE; www.gpluse. $\mathrm{eu}$ ). The content of the paper reflects only the view of the authors; the European Community is not liable for any use that may be made of the information contained in this publication. Jérémie Vandenplas (contributing to this research as a research fellow) and Nicolas Gengler (as a former senior research associate) acknowledge the support of the National Fund for Scientific Research (Brussels, Belgium). The authors also acknowledge Hana Belmabrouk (Gembloux Agro-Bio Tech, University of Liège, Belgium) for her very important contributions in early phases of this research. Computational resources have been provided by the Consortium des Equipements de Calcul Intensif (CECI) of the Federation Wallonia-Brussels (Brussels, Belgium), funded by the National Fund for Scientific Research (Brussels, Belgium) under Grant No. 2.5020.11. The helpful comments and suggestions of 2 anonymous reviewers are gratefully acknowledged.

\section{REFERENCES}

Ali, T. E., and L. R. Schaeffer. 1987. Accounting for covariances among test day milk yields in dairy cows. Can. J. Anim. Sci. 67:637-644.

Bittante, G., and A. Cecchinato. 2013. Genetic analysis of the Fouriertransform infrared spectra of bovine milk with emphasis on individual wavelengths related to specific chemical bonds. J. Dairy Sci. 96:5991-6006. https://doi.org/10.3168/jds.2013-6583.

Bohmanova, J., J. Jamrozik, and F. Miglior. 2009. Effect of pregnancy on production traits of Canadian Holstein cows. J. Dairy Sci. 92:2947-2959. https://doi.org/10.3168/jds.2008-1782.
Bonfatti, V.. G. Di Martino, and P. Carnier. 2011. Effectiveness of mid-infrared spectroscopy for the detailed protein composition and contents of protein genetic variants of individual milk of Simmental cows. J. Dairy Sci. 94:5776-5785. https://doi.org/10.3168/ jds.2011-4401.

Dagnachew, B. S., T. H. E. Meuwissen, and T. Ådnøy. 2013. Genetic components of milk Fourier-transform infrared spectra used to predict breeding values for milk composition and quality traits in dairy goats. J. Dairy Sci. 96:5933-5942. https://doi.org/10.3168/ jds.2012-6068.

De Marchi, M., V. Toffanin, M. Cassandro, and M. Penasa. 2014. Invited review: Mid-infrared spectroscopy as phenotyping tool for milk traits. J. Dairy Sci. 97:1171-1186. https://doi.org/10.3168/ jds.2013-6799.

Egger-Danner, C., J. B. Cole, J. E. Pryce, N. Gengler, B. Heringstad, A. Bradley, and K. F. Stock. 2015. Invited review: Overview of new traits and phenotyping strategies in dairy cattle with a focus on functional traits. Animal 9:191-207.

Friggens, N. C., and M. G. G. Chagunda. 2005. Prediction of the reproductive status of cattle on the basis of milk progesterone measures: Model description. Theriogenology 64:155-190. https:// doi.org/10.1016/j.theriogenology.2004.11.014.

Gajewski, Z., N. M. De Sousa, J. F. Beckers, B. Pawlinski, M. Olszewska, R. Thun, and M. Kleczkowski. 2008. Concentration of bovine pregnancy associated glycoprotein in plasma and milk: Its application for pregnancy diagnosis in cows. J. Physiol. Pharmacol. 59:55-64.

Gengler, N., H. Soyeurt, F. Dehareng, C. Bastin, F. Colinet, H. Hammami, M.-L. Vanrobays, A. Lainé, S. Vanderick, C. Grelet, A. Vanlierde, E. Froidmont, and P. Dardenne. 2016. Capitalizing on fine milk composition for breeding and management of dairy cows. J. Dairy Sci. 99:4071-4079. https://doi.org/10.3168/jds.2015-10140.

Gengler, N., A. Tijani, G.R. Wiggans, and I. Misztal. 1999. Estimation of (co)variance function coefficients for test day yield with a expectation-maximization restricted maximum likelihood algorithm. J. Dairy Sci. 82:1849.e1-1849.e23.https://doi.org/10.3168/ jds.S0022-0302(99)75417-2.

Gengler, N., and G. R. Wiggans. 2001. Variance of effects of lactation stage within herd by herd yield. J. Dairy Sci. 84(Suppl. 1):216 (Abstr.).

Grelet, C., C. Bastin, M. Gelé, J-B. Davière, M. Johan, A. Werner, R. Reding, J.A. Fernández Pierna, F.G. Colinet, P. Dardenne, N. Gengler, H. Soyeurt, and F. Dehareng. 2016. Development of Fourier transform mid-infrared calibrations to predict acetone, $\beta$-hydroxybutyrate, and citrate contents in bovine milk through a European dairy network. J. Dairy Sci. 99:4816-4825. https://doi. org/10.3168/jds.2015-10477.

Grelet, C., J. A. Fernández Pierna, P. Dardenne, V. Baeten, and F. Dehareng. 2015. Standardization of milk mid-infrared spectra from a European dairy network. J. Dairy Sci. 98:2150-2160. https://doi. org/10.3168/jds.2014-8764.

Hammami, H., J. Vandenplas, M.-L. Vanrobays, B. Rekik, C. Bastin, and N. Gengler. 2015. Genetic analysis of heat stress effects on yield traits, udder health, and fatty acids of Walloon Hol- 
stein cows. J. Dairy Sci. 98:4956-4968. https://doi.org/10.3168/ jds.2014-9148.

International Committee for Animal Recording (ICAR). 2012. International agreement on recording practices. ICAR Recording Guidelines. Approved by the general assembly held in Cork, Ireland on June 2012. ICAR, Rome, Italy.

Loker, S., F. Miglior, J. Bohamanova, J. Jamrozik, and L. R. Schaeffer. 2009. Phenotypic analysis of pregnancy effect on milk, fat and protein yields of Canadian Ayrshire, Jersey, Brown Swiss, and Guernsey breeds. J. Dairy Sci. 92:1300-1312. https://doi. org/10.3168/jds.2008-1425.

McParland, S., G. Banos, E. Wall, M. P. Coffey, H. Soyeurt, R. F. Veerkamp, and D. P. Berry. 2011. The use of mid-infrared spectrometry to predict body energy status of Holstein cows. J. Dairy Sci. 94:3651-3661. https://doi.org/10.3168/jds.2010-3965.

McParland, S., and D. P. Berry. 2016. The potential of Fourier transform infrared spectroscopy of milk samples to predict energy intake and efficiency in dairy cows. J. Dairy Sci. 99:4056-4070. https://doi.org/10.3168/jds.2015-10051.

Misztal, I. 2012. BLUPF90 Family of Programs. Accessed August 2015. http://nce.ads.uga.edu/wiki/doku.php/.

Olori, V. E., S. Brotherstone, W. G. Hill, and B. J. McGuirk. 1997. Effect of gestation stage on milk yield and composition in Holstein Friesian dairy cattle. Livest. Prod. Sci. 52:167-176.

Penasa, M., M. De Marchi, and M. Cassandro. 2016. Short communication: Effects of pregnanncy on milk yield, composition traits, and coagulation properties of Holstein cows. J. Dairy Sci. 99:48644869. https://doi.org/10.3168/jds.2015-10168.

Robinson, G. K. 1991. That BLUP is a good thing: The estimation of random effects. Stat. Sci. 6:15-32. https://doi.org/10.1214/ ss $/ 1177011926$.

Rutten, M. J. M., H. Bovenhuis, K. A. Hettinga, H. J. F. van Valenberg, and J. A. M. van Arendonk. 2009. Predicting bovine milk fat composition using infrared spectroscopy based on milk samples collected in winter and summer. J. Dairy Sci. 92:6202-6209. https://doi.org/10.3168/jds.2009-2456.

Silvestre, A. M., F. Petim-Batista, and J. Colaço. 2006. The accuracy of seven mathematical functions in modeling dairy cattle lactation curves based on test-day records from varying sample schemes. J. Dairy Sci. 89:1813-1821.

Socrates, G. 1980, Infrared Characteristic Group Frequencies. 2nd ed. Wiley \& Sons Ltd., Chichester, UK.

Soyeurt, H., D. Bruwier, J.-M. Romnee, N. Gengler, C. Bertozzi, D. Veselko, and P. Dardenne. 2009. Potential estimation of major mineral contents in cow milk using mid-infrared spectrometry. J. Dairy Sci. 92:2444-2454. https://doi.org/10.3168/jds.2008-1734.

Soyeurt, H., P. Dardenne, F. Dehareng, G. Lognay, D. Veselko, M. Marlier, C. Bertozzi, P. Mayeres, and N. Gengler. 2006. Estimating fatty acid content in cow milk using mid-infrared spectrometry. J. Dairy Sci. 89:3690-3695.

Soyeurt, H., F. Dehareng, N. Gengler, S. McParland, E. Wall, D. P. Berry, M. Coffey, and P. Dardenne. 2011. Mid-infrared prediction of bovine milk fatty acids across multiple breeds, production systems, and countries. J. Dairy Sci. 94:1657-1667. https://doi org/10.3168/jds.2010-3408.

Soyeurt, H., I. Misztal, and N. Gengler. 2010. Genetic variability of milk components based on mid-infrared spectral data. J. Dairy Sci. 93:1722-1728. https://doi.org/10.3168/jds.2009-2614.

Toffanin, V., M. De Marchi, N. Lopez-Villalobos, and M. Cassandro. 2015. Effectiveness of mid-infrared spectroscopy for prediction of the contents of calcium and phosphorus, and titrable acidity of milk and their relationship with milk quality and coagulation properties. Int. Dairy J. 41:68-73. https://doi.org/10.1016/j. idairyj.2014.10.002.

van der Drift, S. G. A., R. Jorritsma, J. T. Schonewille, H. M. Knijn, and J. A. Stegeman. 2012. Routine detection of hyperketonemia in dairy cows using Fourier transform infrared spectroscopy analysis of $\beta$-hydroxybutyrate and acetone in milk in combination with test-day information. J. Dairy Sci. 95:4886-4898. https://doi. org/10.3168/jds.2011-4417.

van Knegsel, A. T. M., S. G. A. van der Drift, M. Horneman, A. P. W. de Roos, B. Kemp, and E. A. M. Graat. 2010. Short communication: Ketone body concentration in milk determined by Fourier transform infrared spectroscopy: Value for the detection of hyperketonomia in dairy cows. J. Dairy Sci. 93:3065-3069. https://doi. org/10.3168/jds.2009-2847.

Vanlierde, A., M.-L. Vanrobays, F. Dehareng, E. Froidmont, H. Soyeurt, S. McParland, E. Lewis, M. H. Deighton, F. Grandl, M. Kreuzer, B. Gredler, P. Dardenne, and N. Gengler. 2015. Hot Topic: Innovative lactation stage dependent prediction of methane emissions from milk mid-infrared spectra. J. Dairy Sci. 98:57405747. https://doi.org/10.3168/jds.2014-8436.

Wang, Q., A. Hulzebosch, and H. Bovenhuis. 2016. Genetic and environmental variation in bovine milk infrared spectra. J. Dairy Sci. 99:6793-6803. https://doi.org/10.3168/jds.2015-10488. 